\title{
The Level of Knowledge about HIV/AIDS among Junior Secondary School Teachers in Osun State, Nigeria
}

\author{
Olufunmiso Olatunbosun Ajala
}

\begin{abstract}
This study was carried out to determine the level of knowledge about HIV/AIDS among Junior Secondary School Teachers in Osun State, Nigeria. Knowledge about HIV/AIDS is vital to enable people have the understanding of the modes of transmission and prevention strategies of HIV/AIDS, and thus, teachers are expected to play a pivotal role in transmitting the information to the students leading to behavioural change among students. The questionnaire used was administered on 300 subjects. The research tool was validated by some health experts and educationists and the test retest reliability was 0.83 percentage was used as the statistical tool. It was discovered that the teachers had some basic knowledge about HIV/AIDS: knowledge of facts about HIV/AIDS, knowledge of modes of transmission, sources of HIV/AIDS information and knowledge about signs and symptoms. The researcher considered $69.51 \%$ score on general knowledge about HIV/AIDS as low for teachers upon whom the responsibility of transmission of information about HIV/AIDS lies. It was recommended among others that HIV/AIDS education should be a part of the teacher training curriculum in the country.
\end{abstract}

Index Terms-HIIV/AIDS, junior secondary school, knowledge, transmission.

\section{INTRODUCTION}

Acquired Immune Deficiency Syndrome (AIDS) is a disease caused by a virus named Human Immune Deficiency Virus (HIV), which destroys the immune system of the human body. Since it was first reported among homosexuals in the United State in 1981, HIV has had its most profound effect on people of sub Saharan Africa. The HIV/AIDS pandemic has not only been the worst tragedy in contemporary history, but has also posed serious demographic, humanitarian, economic and developmental crisis [1]. By the end of 2005, the estimated number of people living globally with HIV/AIDS was estimated to be 40.3 million, while newly infected persons and deaths due to HIV/AIDS in 2005 alone were put at 4.9million and 3.1million, respectively [2].

Approximately $60 \%$ (25.8million) of HIV infected people are in sub-Saharan Africa, whereas the people in the region constitute just a like over $10 \%$ of the world population. Furthermore, new infections and deaths due to HIV in sub Saharan Africa were 3.2 and 2.4 million, respectively during the period [3]. The first round of HIV sentinel surveillance conducted in Nigeria covering nine states found an adult HIV prevalence rate of $1.8 \%$, which has increased to $5.8 \%$ in 2001 [4]. The statistics of [4] put the estimate of Nigeria living with HIV at 3.3 million adults or $5.4 \%$ of adult population, the

Manuscript received May 2, 2015; revised September 25, 2015.

O. O. Ajala is with the Department of Integrated Science, Osun State College of Education, Ilesa, Nigeria (e-mail: funsoajala@yahoo.com). third highest in the world after South Africa and India [5]. Even with these HIV figures for Nigeria, [6] opined that the probability of understanding of the real magnitude of reporting and inadequate facilities for HIV testing.

Since the beginning of the epidemic, almost 78 million people have been infected with the HIV virus and about 39 million people have died of HIV. Globally, 35 million (33.2-37.2million) people were living with HIV, at the end of 2013. An estimated 0.8 of adults aged $15-49$ years worldwide are living with HIV, although the burden of the epidemic continues to vary considerably between countries and regions. Sub Saharan Africa remains most severely affected, with nearly 1 in every 20 adults living with HIV and accounting for nearly $71 \%$. [7].

According to [7], the first AIDS case in Nigeria was reported in 1987. As at March, 1990 the AIDS situation in the country was as follows:

- 70,000 screened

- 308 confirmed seroportius

- 21 dead

He noted that in general Nigeria has shown little interest in AIDS pandemic. The factors that have contributed to the spread of HIV in Nigeria and indeed in other parts of Africa include poverty, poor health status, low literacy level, high number of young people, inadequate knowledge about the disease, cultural paradigm that encourage promiscuity such as polygamy, violence and cultural pressure to present ones premarital relationship as moral thus preventing young girls from negotiating safer sex [8]-[10].

Since the beginning of the epidemics, almost 78 million people have been infection with HIV virus and about 39 million people have died of HIV.

Globally, 35.0 million (33.2 - 37.2 million) people were living with HIV, although the burden of the epidemic continues to vary considerably between countries and regions. Sub-saharan Africa remains most severely affected, with nearly 1 in even 20 adults living with HIV and accounting for nearly $71 \%$ of the people living with HIV worldwide [11].

As at now, no cure has been found for HIV/AIDS, and until a vaccine is found, provision of correct information will remain one of the key prevention strategies recommended against HIV/AIDS. Consequently, school going children are expected to be educated on HIV and other sexually transmitted diseases. The Nigeria Education Research and Development council (NERDC) produced a National Sexuality Education Curriculum, which has since been introduced into all the nation's primary and secondary schools. The school teachers' knowledge about HIV/AIDS is very important so that they can impart accurate knowledge about the disease to the school children who ultimately serve as 
catalytic agent to propagate accurate information about HIV/AIDS in their community. It is easy to establish protective behaviour that will last into adulthood at young age [12]. This study set out to evaluate the level of knowledge about HIV/AIDS among Junior Secondary School teachers in Osun State, Nigeria.

\section{Methodology}

The population for the study constituted the Junior Secondary School teachers in 30 Local Government Areas of Osun State, Nigeria. Ten teachers were selected from each of the 30 Local Government Areas of the State and 300 questionnaires administered to them. Out of the 300 questionnaires, only 212 were completed.

\section{INSTRUMENT}

The questionnaire was drafted based on review of literature, it was reviewed and validated by some health experts and educationists, and it was pretested on 30 Junior Secondary School teachers in Ilesa, Osun State, Nigeria. The questionnaire consisted of both the personal data and the knowledge of HIV/AIDS sections. Basic knowledge about HIV/AIDS, five items; knowledge of methods of transmission, five items; knowledge of symptoms of HIV/AIDS, four items and six items on how HIV/AIDS cannot spread (myths about HIV).

\section{RESULTS}

Out of 212 respondents, 80 were males $(37.7 \%)$ and 102 were females $(62.3 \%)$. The results were presented in Table I to Table $\mathrm{V}$ below:

TABLE I: BASIC KNOWLEDGE OF FACTS ABOUT HIV/AIDS

\begin{tabular}{|l|l|l|l|}
\hline ITEM & \multicolumn{3}{|c|}{ RESPONSES } \\
\hline $\begin{array}{l}\text { HIV/AIDS is an infectious } \\
\text { disease }\end{array}$ & True & False & Total \\
\hline $\begin{array}{l}\text { The human immune deficiency } \\
\text { virus(HIV) is the AIDS Virus }\end{array}$ & 194 & 4 & 212 \\
\hline There is no cure for AIDS & 190 & 82 & 212 \\
\hline $\begin{array}{l}\text { HIV positive individuals usually } \\
\text { look healthy }\end{array}$ & 139 & 73 & 212 \\
\hline $\begin{array}{l}\text { Infection with other sexually } \\
\text { transmitted diseases increases the } \\
\text { chances of HIV transmission. }\end{array}$ & 157 & 55 & 212 \\
\hline Total & 828 & 232 & 1060 \\
\hline Percentage & $80.94 \%$ & $19.06 \%$ & $100 \%$ \\
\hline
\end{tabular}

Table I shows that $80.94 \%$ of the junior secondary school teachers surveyed in this study had basic knowledge about acquired immune deficiency syndrome while $19.06 \%$ of the respondents did not have basic knowledge about it.

Table II indicates that $92.45 \%$ of respondents in the prevent study had knowledge about transmission of AIDS while $7.55 \%$ had no knowledge about transmission of the disease.

In Table III, $53.30 \%$ of the sampled Junior Secondary School Teachers had knowledge about symptoms of acquire immune deficiency syndrome (AIDS) while 46.70\% not having knowledge symptoms of the disease.

TABLE II: KNOWLEDGE ABOUT MODES OF TRANSMISSION OF HIV/AIDS
\begin{tabular}{|l|l|l|l|}
\hline ITEM & \multicolumn{3}{|c|}{ RESPONSES } \\
\hline & True & False & Total \\
\hline $\begin{array}{l}\text { AIDS virus can be transmitted } \\
\text { from an infected person with no } \\
\text { symptoms as well as from people } \\
\text { with AIDS }\end{array}$ & 196 & 16 & 212 \\
\hline $\begin{array}{l}\text { AIDS virus can be spread/ } \\
\text { contracted through sexual } \\
\text { intercourse. }\end{array}$ & 206 & 126 & 212 \\
\hline $\begin{array}{l}\text { AIDS virus can be spread/ } \\
\text { contracted by having infection } \\
\text { from a quack health personnel } \\
\text { and by using unsterilized blade } \\
\text { and syringe }\end{array}$ & 182 & 30 & 212 \\
\hline $\begin{array}{l}\text { Receiving untested blood make } \\
\text { one to be at risk of contracting } \\
\text { AIDS virus }\end{array}$ & 206 & 06 & 212 \\
\hline $\begin{array}{l}\text { AIDS virus can be spread from } \\
\text { the mother to her unborn child } \\
\text { during pregnancy or delivery }\end{array}$ & 190 & 22 & 212 \\
\hline Total & 980 & 80 & 1060 \\
\hline Percentage & $92.45 \%$ & $7.55 \%$ & $100 \%$ \\
\hline
\end{tabular}

TABLE III: KNOWLEDGE ABOUT SYMPTOMS OF AIDS
\begin{tabular}{|l|l|l|l|}
\hline ITEM & \multicolumn{3}{|c|}{ RESPONSES } \\
\hline & True & False & Total \\
\hline $\begin{array}{l}\text { Loss of more than 10\% body } \\
\text { weight is a major sign of AIDS }\end{array}$ & 126 & 86 & 212 \\
\hline $\begin{array}{l}\text { Chronic diarrhea for more than 1 } \\
\text { month is a major sign of AIDS }\end{array}$ & 122 & 90 & 212 \\
\hline $\begin{array}{l}\text { Prolonged fever for more than 1 } \\
\text { month is a major sign of AIDS }\end{array}$ & 104 & 108 & 212 \\
\hline $\begin{array}{l}\text { Persistent cough for more than 1 } \\
\text { month is a minor sign of AIDS }\end{array}$ & 100 & 112 & 212 \\
\hline Total & 452 & 396 & 848 \\
\hline Percentage & $53.30 \%$ & $46.70 \%$ & $100 \%$ \\
\hline
\end{tabular}

TABLE IV: KNOWLEDGE ABOUT How AIDS CANNOT Be SPREAD, MythS ASSOCIATED WITH AIDS

\begin{tabular}{|l|l|l|l|}
\hline ITEM & \multicolumn{3}{|c|}{ RESPONSES } \\
\hline $\begin{array}{l}\text { AIDS virus can be } \\
\text { contracted/spread through } \\
\text { shaking of hand }\end{array}$ & 82 & 130 & 212 \\
\hline $\begin{array}{l}\text { AIDS virus can be spread through } \\
\text { living with AIDS patients }\end{array}$ & 114 & 98 & 212 \\
\hline $\begin{array}{l}\text { AIDS virus can be contracted } \\
\text { while eating with AIDS patient }\end{array}$ & 108 & 104 & 212 \\
\hline $\begin{array}{l}\text { Using the same toilet with an } \\
\text { AIDS patient can make one to be } \\
\text { infected with the disease }\end{array}$ & 120 & 92 & 212 \\
\hline Total & 520 & 540 & 1060 \\
\hline Percentage & $49.06 \%$ & $50.94 \%$ & $100 \%$ \\
\hline
\end{tabular}

In Table IV above, $49.06 \%$ of the respondents picked negative statements concerning the myths associated with the spread of aids while $50.9 \%$ disagreed with all the negative statement concerning the myths associated with spread of aids.

In Table $\mathrm{V}$ below on general knowledge about AIDS (Summary of Table I - Table IV), 64.48\% of the respondents had general knowledge as against $30.52 \%$ that did not have general knowledge about AIDS. 
TABLE V: GENERAL KNOWLEDGE ABOUT AIDS

\begin{tabular}{|l|l|l|l|}
\hline Unit of Knowledge & True & False & Total \\
\hline Basic knowledge about AIDS & 828 & 232 & 1060 \\
\hline $\begin{array}{l}\text { Knowledge about aids } \\
\text { transmission }\end{array}$ & 980 & 80 & 1060 \\
\hline Knowledge about signs of aids & 452 & 396 & 848 \\
\hline Knowledge on myths about aids & 540 & 520 & 1060 \\
\hline Total & 2800 & 1228 & 4028 \\
\hline Percentage & $69.51 \%$ & $30.49 \%$ & $100 \%$ \\
\hline
\end{tabular}

\section{DISCUSSION OF FINDINGS}

The analysis of data revealed that:

1) $80.94 \%$ of the Junior secondary school teachers had basic knowledge about AIDS as against $19.06 \%$ that had no basic knowledge of the disease. According to World Consultation of Teachers International Organization and WHO, UNESCO and ILO (no data) in conscience statement on AIDS in schools, noted that active movement of teachers through their representative organization is essential for students to be well informed through education programmes that are meaningful to their lives. There is therefore the need for more teachers to be knowledgeable about AIDS.

2) $92.45 \%$ of the Junior Secondary School teachers had knowledge about the transmission of AIDS as against $7.55 \%$ that did not have. The finding was in line with the view of [13] that treatment are very likely to be effective if there is early knowledge of HIV infection. [14] avoided that one of the ten points on AIDS for World AIDS Days was that to know how HIV spreads is to know how to prevent infections:

3) $53.30 \%$ of the Junior Secondary School Teachers had knowledge of symptoms of AIDS as against 46.70 that did not have. [15] believes that health education is very important in making people to be aware on how to protect themselves from infections. Teachers can only teach what they know. A situation wherein $46.70 \%$ of teachers did not know signs of AIDS is not only unhealthy for them but for the pupils they were to teach.

4) $49.06 \%$ of the teachers make negative statement concerning the myths associated with the spread of AIDS while $50.94 \%$ disagreed with the negative statement concerning the myths. This shows that $49.06 \%$ of the respondents did not know how AIDS virus can be spread while $50.94 \%$ did. Their responses ran contrary to [16] views that AIDS is not spread through casual contact such as at work or at school, touching or hugging, shaking hand, coughing or sneezing, insect bites, water or food, cup, glasses, plates, toilet, swimming in pools or public paths.

5) When all the response were compressed under Table V to find out the general knowledge of Junior Secondary School Teachers about AIDS, 69.51\% had general knowledge about AIDS as against $30.49 \%$ that did not have general knowledge about AIDS. The findings was nearly similar to the findings of [17] where upon analysis, $60.49 \%$ of respondent had knowledge of AIDS as against $39.51 \%$ that did not differ as the early study of one of the researchers cited was based on college athletes.

6) Ref. [17] noted that increase in knowledge reduces the tendency generally coursed by fear to stigmatize AIDS patients. Open discussion about the disease and support for the prevention and control programme require an informed public.

\section{CONCLUSION}

Result of the findings indicated that the knowledge of Junior Secondary School Teachers, upon whom responsibility of transmitting HIV/AIDS information to the students lies, is too low. Increase in knowledge of the teachers will ultimately lead to a corresponding increase in the level of awareness of the students about HIV/AIDS thus resulting in taking preventive measures and reducing level of stigmatization of people living with HIV/AIDS.

\section{RECOMMENDATIONS}

The Junior Secondary School Teachers had some basic knowledge about AIDS. Knowledge about AIDS transmission, knowledge on myth about how AIDS spread however, the researcher considered $69.51 \%$ score on general knowledge about AIDS as low for teachers who we purported to teach pupils AIDS education. On the basis of this, the following recommendations are made:

- National advisory expert committee on AIDS should design and implement in-service training programme on AIDS education for Junior Secondary School Teachers.

- AIDS education should be an integral part of teaching programme in the country.

- The various levels of government in the country should intensify war against AIDS

- AIDS education in school should be vigorously pursued.

- Workshops, in- service training and group discussions should be organized for teachers on HIV/AIDS.

- The ministry of education must also commit their efforts to the provision of training of teachers, curriculum development and provision of adequate teaching aids.

- Another avenue of getting HIV/ADIS messages across to students and the community in general that has not been widely explored in Nigeria is the library.

- The internet which has become powerful source of information for knowledge and as a teaching tool [18] should be utilized in getting HIV/AIDS information across to students and community.

- As relevant empirical literature posed a limiting factor in these studies, more research should be done on AIDS in this country some of the research should be funded by government and non government organizations.

\section{REFERENCES}

[1] E. O. Ogunbodede, "HIV/AIDS situation in Africa," Int. Dent. J., vol. 54, no. 6, pp. 352-360, 2004.

[2] UNIADS/WHO AIDS epidemic update, Joint United Nations, December 2005.

[3] O. M. Bankole and O. O. Mabekoje, "Awareness and opinions about HIV/AIDS among secondary school teachers in Ogun State, Nigeria," Scientific Research and Essay, vol. 3, no. 6, pp. 245-253, June 2008.

[4] UNAIDS/WHO AIDS epidemic update. (December 2004). [Online] Available: http:/www.unaids.org/wad2004/EPI_1204_pdf_en.pdf

[5] Federal Ministry of Health, A Technical Report: The 2001 National, HIV/Syphilis, 2001. 
[6] O. Alubo, "Breaking the wall of silence: Policy and politics in Nigeria," Int. J. Health Services, vol. 32, no. 6, pp. 551-556, 2002.

[7] World Health Organization (WHO), "Sexually transmitted infections. Briefing kits for teachers," Geneva, WHO Regional Office for the Western Pacific, 2001.

[8] C. Lau and S. Muula, "HIV/AIDS in sub Saharan Africa," Croat. Med. J., vol. 45, no. 4, pp. 402-414, 2004.

[9] D.J. Smith, "Premarital sex, procreation and HIV risk in Nigeria," Studies in Family Planning, vol. 35, no. 4, pp. 223-235, 2004.

[10] A. T. Owolabi, A. A. Onayade, I. O. Ogunlola, S. O. Ogunniyi, and O. Kuti, "Sexual behaviour of secondary school adolescents in Ilesa, Nigeria: Implications for the spread of STIs including HIV/AIDS," $J$. Obstet. Gynaecol., vol. 25, no. 2, pp. 174-178, 2005.

[11] World Health Organization Global Health Observation (GHO), HIV/AIDS Global situation and Trends, 2014

[12] Federal Ministry of Education, "National sexuality education," Curriculum of Upper Primary school, Junior Secondary Schools, Senior Secondary schools, Tertiary Institutions, National Education Research and Development Council, Abuja, 2002.

[13] AIDS/STD Unit, "AIDS testing what you need to know," Malborize Publication Unit, Health Department, 1990.

[14] World Health Organization, "Guide to planning health promotion for AIDS prevention and control Geneva," 1989.

[15] B. Robinson, "What is AIDS manual for health workers," General: Children Medical Commission, 1988.

[16] E. A. Achalu, "AIDS and other sexually transmitted diseases," Simarch Nig. Ltd, $2^{\text {nd }}$ ed., Lagos, pp. 37-44, 1993.

[17] O. A. Moronkola, "Inter colligate athletes knowledge attitude towards AIDS and their sexual practices," Sports Science and medicine, vol. 2 , pp. 110-114, 1992.
[18] W. S. Luan, N. S. Fung, M. Nawawi, and T. S. Hong, "Experienced and inexperienced internet users among pre-service teachers," Their Use and Attitudes toward the Internet Educational Technology and Society, vol. 8, pp. 90-103, 2005.

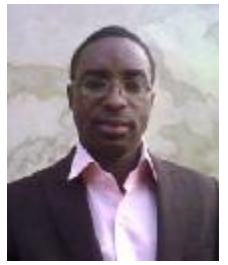

Olufunmiso Olatunbosun Ajala was born in 1970 at Gbongan, Osun State, Nigeria. He possesses the bachelors of science (B.Sc) chemistry and the master of education (science education) from Obafemi Awolowo University, Ile-Ife. He also has post graduate diploma in education (PGDE) from National Teachers' Institute (NTI), Kaduna, the masters of business administration from Obafemi Awolowo University Ile-Ife and diploma in computer studies from Osun State College of Education, Ilesa. He is currently pursuing his Ph.D degree in science education at Ekiti State University, Ado Ekiti, Nigeria.

$\mathrm{He}$ is a senior lecturer and the current head of the Department of Integrated Science, Osun State College of Education, Ilesa, Nigeria. His experience in teaching integrated science both at Nigeria Certificate in Education (NCE) and Degree (University of Ibadan B.Ed) levels spans nineteen years.

Mr. Ajala has sixteen article published in reputable journals and two others already accepted for publication. He has presented fourteen academic papers in relevant conferences. His research interest tends towards the role of integrated science curriculum in providing science literacy to Nigeria children as well as the availability and adequacy of laboratory equipment and chemicals. 